\title{
Review of Camel Calves Nutrition and Management in Kenya
}

\author{
Tura Isako* King'ori A. M Ondiek J. O Onjoro P. A \\ Department of Animal Science, Egerton University, P.O Box 536-20115 Egerton, Kenya
}

\begin{abstract}
Camels are important livestock species in the arid and semi-arid lands (ASALs) of Kenya. Camels provide milk, meat and serves as means of transport (drawing water, carry make shift houses, elderly people and children) for mobile pastoral communities. They supply milk and meat even during dry and drought periods when other livestock species struggle for their survival. Production systems for the camels are largely extensive with camel husbandry techniques mainly inherited from pastoral traditional knowledge passed down over generations. High calf mortality (about 63\%) is a common phenomenon in the pastoral production systems of northern Kenya. A review was conducted to established causes of the high mortality and recommendations developed with a view to reduce mortality to manageable levels. This review showed that calf colostrum suckling restriction at birth, calf diarrhoea and other diseases, milk competition with calves for household consumption and income generation and limited forages during droughts were among the major causes of camel calf mortality. The review consolidated previous research on camel calves' nutrition and management and has recommended nutrition and management tips to reduce mortality.
\end{abstract}

Key words: calve mortality, milk competition, colostrum, supplementation, milk replacer.

DOI: $10.7176 / \mathrm{JNSR} / 10-8-04$

Publication date: April $30^{\text {th }} 2020$

\section{Introduction}

Camels are resilient livestock species that provide constant supply of milk and meat under harsh conditions in arid and semi-arid areas of Kenya (Tura et. al, 2010). Camels are at the epicenter of pastoral livelihoods and considered sacred animal for enabling camel keepers to survive in harsh ASALs conditions (Tura, et. al 2010). They provide pastoral communities with income, food, transport and social benefits such as prestige, cultural uses, insurance and risk buffering options (Bekele, 2014). Camels in Kenya are kept traditionally in arid areas of northern Kenya by pastoralists who are endowed with indigenous knowledge gathered over several generations. As a response to changing climate, rangelands degradation, loss of palatable range grasses and bush encroachment, camels are adapted as mitigation measures by many traditionally cattle keeping communities in Kenya, a trend that is increasing.

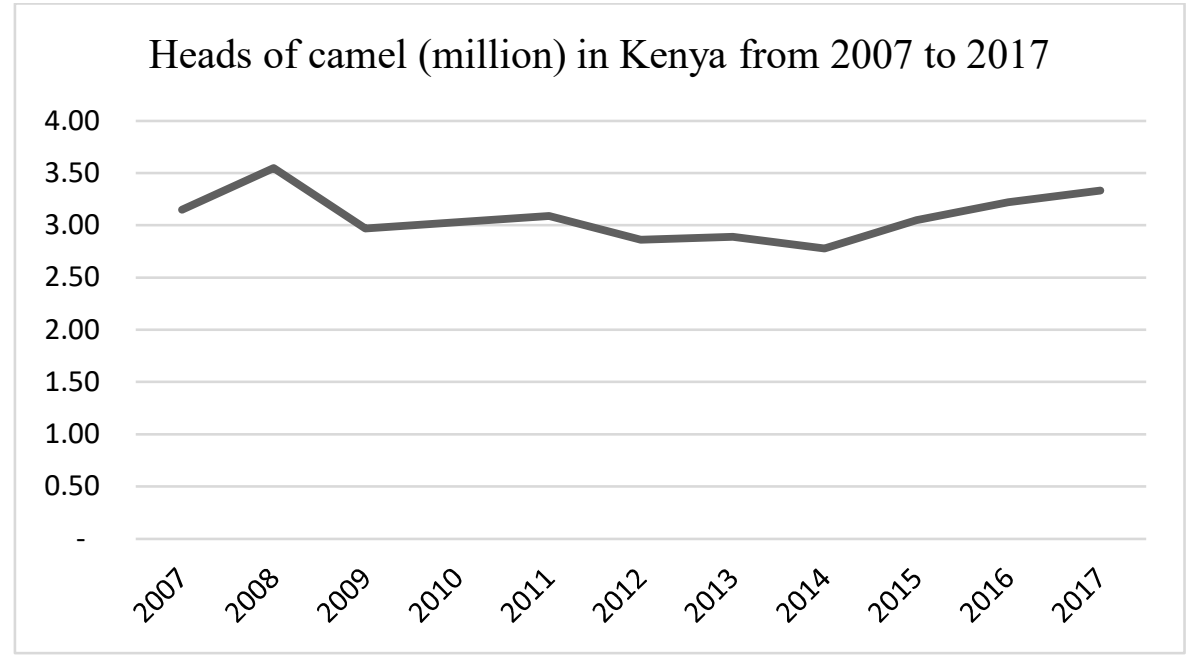

Figure 1 : Camel population trends in Kenya between 1997 and 2017 (FAOSTAT, 2019)

Rearing of camel calves under traditional pastoral production systems is faced with limited feeds and diseases among other challenges. Competition for milk by pastoralists and calves is among the key feed factor. High mortality rates of up to $63 \%$ in pastoral herds in northern Kenya has been reported by several authors (Kaufmann, 1998; Njanja, 2007). The high camel calves' mortality has resulted to slow camel population growth limiting them to subsistence use despite their products' worldwide demand. The objective of this review was to consolidate the research on camel calf nutrition and management. In addition, availing knowledge to camel keepers, and subsequently recommend nutrition and management package that will reduce camel calf mortality and unlock camel potential for commercialization. 


\subsection{Camel calf rearing systems}

The rearing of camel calves under traditional pastoral production systems in Ethiopia was reported to be faced with several challenges resulting in retarded growth and high death rate of calves (Yesihak and Bekele, (2004). In Kenya, mortality rates between $12-63 \%$ have been reported in extensive pastoral production system (Peter, 2010, $\mathrm{KCA}, 2012$ ). Under ranching conditions in laikipia ranches of Kenya; calf mortality rates of less than $25 \%$ was reported (Browne and Deem, 2012).

The performance of camel calves in different rearing systems has been studied. Bakheit et al., (2017) observed the body weight of Sudanese Arabi Kababish calves reared under semi-intensive system (SIS) and in traditional system (TS). The SIS had the calves suckle dams and take supplementation diets (one $\mathrm{kg}$ of concentrate/head/day), ad libitum watering, health care and spraying weekly against ticks and external parasite. The SIS weights were significantly higher $(123 \pm 2.21,221 \pm 2.17$ and $326 \pm 2.40 \mathrm{~kg})$, than in TS $(96 \pm 1.59,159$ \pm 2.35 and $208 \pm 2.50 \mathrm{~kg}$ at 6,12 and 18 months respectively. These differences between systems of management were highly significant $(\mathrm{P}<0.01)$.

Similarly, Bhakta et al., 2010, compared the Indian camel calves aged between 7 to 10 months reared under intensive (IS) and semi-intensive system (SIS). The IS reared calves on concentrate supplementation at $1 \mathrm{~kg} / \mathrm{calf} /$ day while SIS provided daily grazing / browsing for about 6 to 7 hours and offered fodder in the evening. The study reported that after a 170-day trial, the mean body weight, the mean growth rate and the total gain were significantly $(\mathrm{P}<0.01)$ higher in IS as compared to SIS. Similarly, the mean fodder intake per calf per day was higher in the IS compared to SIS group.

\subsection{Camel calf mortality}

Camel calves are the foundation of a camel herd and form the replacement stock without which herd growth is unlikely. Poor management practices are cited among the reasons why large number of calves (ranging from 12$63 \%$ ) die in Kenya's pastoral camel herds (KCA, 2012). Traditionally, camel keepers believe that the calf's fate after birth is "God's will", yet the numerous causes of calf mortality can be avoided by good management. A major contributor to the high camel calf mortality is reported to be denial of access to colostrum for the young ones. Peter (2010) reported that $63.3 \%$ of Samburu and Turkana pastoralists in Samburu County denied camel calf access to colostrum. Kamber et al. (2001) showed that low colostrum intake in the 24 hours of life and not low immunoglobulin $\mathrm{G}(\mathrm{IgG})$ concentration caused early camel calf mortality in Laikipia Kenyan ranches. The population of camels in Kenya has potential to grow significantly if proper dam-new born nutrition and management is improved. The dam should be well fed and managed during pregnancy and lactation period. Major areas to consider in calf nutrition are proper colostrum feeding, adequate milk suckling i.e., allow the calf to suckle at least two teats on daily basis, diarrhoea and disease management and proper feeding and watering of weaners after weaning to avoid stress. In Kenya, diseases like haemorrhagic septicaemia commonly called 'swollen gland' kills 20-30\% of camel weaners in extensive pastoral production system (Ndungu et al., 2003).

\section{Camel calf management}

Camel husbandry in Kenya is based on traditional knowledge and beliefs passed down through generations (KCA, 2012). For instance, calf restriction of early colostrum intake by most camel keepers seen as a way of controlling calf scour is detrimental to the survival of the calves.

Compared with the other domesticated livestock species, camels need far less assistance during calving. Lengthy periods of labour as long as 30 hours have been reported to result in normal birth of camels while both 'anterior' (head and forelegs first) and 'posterior' presentations (hind legs first) are considered normal (KCA, 2012). However, according to Tadesse et al., (2017), nonspecific causes were the leading cause of calf mortalities across camel dairy farms in Ethiopia with prevalence of $3.14 \%$ followed by still birth at $1.56 \%$, showcasing the need to have proper care for the dam during late pregnancy and dam-neonate management at early stage of life.

Bekele (2014) also observed among the camel pastoralists in Southern Ethiopia that calf score and mortalities are common among certain parity. His report matched with observations by indigenous camel keepers in Kenya where calf score was reported to be common among the second calvers/parity. The pastoralists manage differently such dams and their neonate from other calves for a period of three to four weeks. When they observe signs of diarrhoea at early stage of life, the dam is exhaustively milked and calf only access very little colostrum and milk during the first three to four weeks of life. On the other hand, if calf does not show any signs of diarrhoea the calf is let to suckle freely without any milking for the same period. Thus future research need to establish why camel calf score is common among second calvers? A study by Ahmed and Hedge (2007) reported high calf mortality (49\%) within the first 3 months and 19\% up to one year. Farah et al. (2007) reported that diarrhoea was the major cause of death $(73 \%)$ in Somalia. It is paramount then that proper calf diarrhoea management is a prerequisite to the success of any camel herd progression. 


\subsection{Pregnant Dam management}

Good camel neonate management ideally start before birth. One month to calving, reservation of good grazing areas near the homestead, devoid of potholes, gullies and slippery ground should be identified for in-calf dams. In addition, close observation during grazing and at night as well as reduced lengthy treks should be observed. Their housing/Boma should be well made to control predators like hyenas and lions to prey on them, cleaned with minimum dust, deep wallowing ground and mud (KCA, 2012). Similarly, all pregnant camels should be vaccinated against tetanus and Clostridium perfringens (type $\mathrm{C}$ and $\mathrm{D}$ ) to ensure adequate amount of clostridial antibodies at parturition (Tibary and Anouassi, 2001). Following delivery, the umbilicus should be tied and dipped in 7\% iodine tincture to prevent umbilical infections (Tibary and Anouassi, 2001).

\subsection{Calf observation at birth}

Early detection of respiratory and cardiovascular difficulties in the new born calf, and subsequent prevention of further complications due to physical and infectious factors increases the chances of camel calf survival. It is therefore crucial to evaluate and offer primary care to the new born camel calf to reduce mortality (Tibary and Anouassi, 2001).

The most vital parameters to observe when evaluating new born camel calves are birth weight, heart rate, type and rhythm of respiration and body temperature. The average normal birth weight ranges from $30 \mathrm{~kg}$ in dromedary camels. It has been reported that the average birth weights among Rendille camels in Marsabit, Kenya was $35 \mathrm{~kg}$ (Kuria, 2004) and dromedary camels in Samburu, Kenya at $47 \mathrm{~kg}$ (Peter, 2010). A very high heart rate of 80 to 120 beats is normal, but with regular respiration of 20 to 30 breaths per minute (Tibary and Anouassi, 2001). Some signs of respiratory difficulties include open mouth breathing, heavy breathing due to collapsed lungs, and presence of fluids or choanal atresia.

The normal body temperature ranges from 37.5 to $39{ }^{\circ} \mathrm{C}$, however shivering observed in the first few hours after birth is a normal occurrence. The suckling reflex is observed within the first 30 minutes after birth with increased salivation and it is important to regularly weigh the calf (every day for the first 2 weeks and every other week thereafter) in order to determine the adequacy of milk intake. All new born should also be examined for any signs of congenital abnormalities like abnormal limb development, atresia ani, cleft palate, abnormal reflexes and blindness. All Camelidae are born in a relatively advanced stage of development and should be relatively active and capable of holding their heads up high as well as standing, nursing and walking unaided within a few minutes to one hour after birth (Tibary and Anouassi, 2001).

\section{Camel calf suckling management}

An optimal level of nutrition in early life will lead to fast growth, early maturity and optimum production in terms of future milk and carcass yield (Kertz et al., 2017). However, camel nutrition research has taken a back seat in recent years. An overview of publications in the Journal of Camel Practice and Research between 2013 and 2017 indicates a greater focus of research in Camelid physiology $(11.11 \%)$, camel milk and pathology $(10.34 \%$ each), parasitology $(9.2 \%)$, diseases $(8.81 \%)$, immunology $(5.75 \%)$, microbiology $(5.36 \%)$, reproduction $(4.98 \%)$, surgery, anatomy and nutrition (4.6\% each). Other areas of research included anaesthesia $(4.21 \%)$, production $(3.45 \%)$, imaging and pharmacology $(3.06 \%$ each), meat $(2.68 \%)$, genetics and breeding $(2.3 \%)$ and serology/vaccinology (1.53\%) (Gahlot, 2018). Some important aspects of calf feeding discussed include, colostrum feeding, feeding of whole milk/ milk replacers and weaning.

\subsection{Colostrum suckling}

Dromedary camels, like all Camelidae are born agammaglobulinemic, and thus lack the placental transfer of immunoglobulins. They completely rely on passive immunity absorbed from maternal colostrum for their immunity during the first weeks of their life (Tibary and Anouassi, 2001). The significance of colostrum feeding is well demonstrated in the new born camels by the increase in total protein and serum IgG and Immunoglobulin M (IgM) concentrations by 24 hours after birth (Tibary and Anouassi, 2001). In addition to the activation of the immune system, recent studies in bovines have illustrated that colostrum contains many hormones and growth factors of the endocrine system, which interact with cells in the gut to program and activate the digestive system and muscle (Ontsouka et al., 2016). It is therefore critical that the new born calf gets colostrum immediately after birth to boost its immune system and provide protein, energy, minerals and vitamins. One of the most important vitamins found in colostrum is ascorbic acid (vitamin C) and it was established by Al-Sultan (2008) that injection of ascorbic acid effectively increases lysosomes concentration. This suggests that the vitamin $\mathrm{C}$ can enhance the immune system in camel calves. Camel calves like other mammals are born without antibodies and active immunoglobulin synthesis starts from two weeks of life, reaching protective level at two to three months of age (Kaufmann, 2003). Tibary and Anouassi (2001) suggested that new born camel calves should receive $10 \%$ of their body weight in colostrum, preferably within the first 12 hours after birth, with half of this amount given in the first 6 hours of birth. If the calf is unable to suckle within 3 hours after birth, then colostrum should be milked out and 
bottle-fed/ hand-fed to the calf. If the calf has a poor suckling reflex, administration of colostrum should be done via tracheal intubation.

\subsection{Handling of colostrum for bottle feeding}

The colostrum of various livestock species has a great potential for bacterial contamination in farms due to poor hygiene (Stewart et al., 2005). Pasteurization of colostrum has been a challenge because of its high protein content, which upon heating increases viscosity and coagulation. The time-temperature conditions of $60 \mathrm{~min}$ at $60^{\circ} \mathrm{C}$ has been described for successful pasteurization of colostrum (Godden et al, 2003) that would decrease colostrum bacteria counts with reduced damage to Ig, vitamins A and E, and $\beta$-carotene (Johnson et al., 2007; Donahue et al., 2012).

Diarrhea was reported to decrease in Bovine calves fed heat-treated colostrum (Godden et al., 2012). Similarly, the calves had greater colonization of Bifido bacteria and less Escherichia coli than those fed unheated colostrum (Malmuthuge et al., 2015), suggesting possible improved gut health. As a consequence, it would be vital for Kenyan pastoral camel keepers to consider heat-treating bottle fed colostrum.

\subsection{Suckling whole milk}

Camel calves hardly survive in the first 8 weeks of life, especially where the mother rejects the calf or dies (KCA, 2012). Provision of adequate amount of milk is important for calf survival, growth, and vigour for the new born calf. As a rule of thumb camel calf should be fed milk equivalent to $8-10 \%$ of its body weight. The calf is dependent on milk until the rumen becomes fully functional usually at 3-4 months of age (Wilson, 1984). The camel calf should be left with the dam for the first month of life to suckle the four quarters. After one month the calf can suckle two teats and the household can milk the other two teats on daily basis (Ouda, 1993).

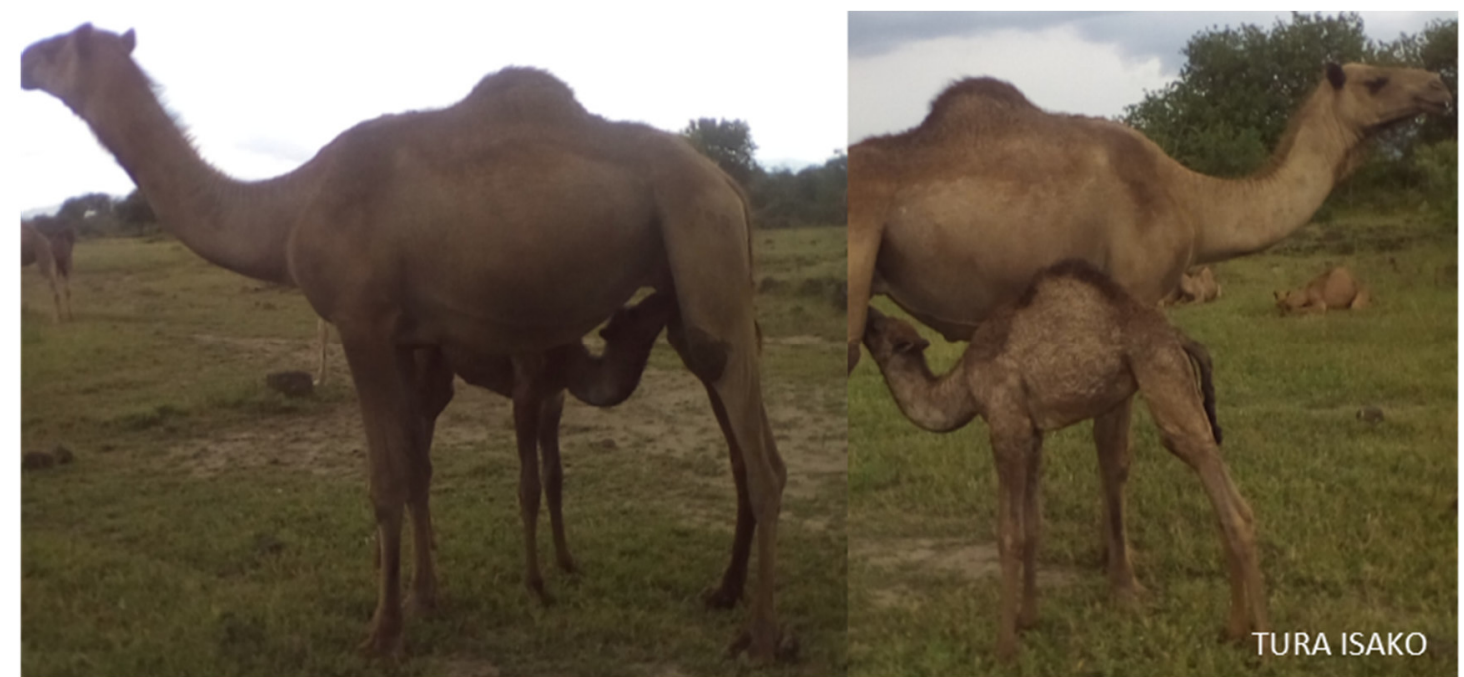

Photo 1: Camel calf left with dam for the first one month

Field (1979a) reported growth rates of $378 \mathrm{~g}$ /day to $655 \mathrm{~g}$ /day where camel calves got up to $75 \%$ of the dam's milk in the dry and wet seasons respectively. In the same environment but under range management where the calf faces enormous competition for the milk, growth rates of $222 \mathrm{~g} /$ and $255 \mathrm{~g} / \mathrm{day}$ in dry and wet seasons were obtained respectively. Peter (2010) reported male and female calf growth rates of $281 \mathrm{~g} /$ day and $168 \mathrm{~g} /$ day respectively and on average $212 \mathrm{~g}$ /day in pastoral production system in Samburu County. The difference in growth indicating the preference of pastoralists for female calves hence receiving more daily milk allocation than male calves.

\subsection{Feeding orphaned camel calves}

Orphaned camel calves are reported to have low survival rates unless colostrum is administered. A healthy camel calf can stand and suckle within two hours after birth while most will walk within five hours and be strong enough to follow their mother within two days of birth (Coventry, 2002).

Fostering the orphan onto a lactating camel can be successful if the calf's 'new' smell is hidden from the foster mother. Then the calf let to freely suckle milk from the mother's udder. Alternatively, the foster mother is left alone with the orphan calf for a day to let the foster dam accept the orphan (Coventry, 2010).

Coventry, (2010) further suggested that following unsuccessful fostering, hand-feeding or bottle-feeding can be done using either camel, cattle or goat colostrum collected within the first three days of lactation, milk collected from camels, cattle and goats. 


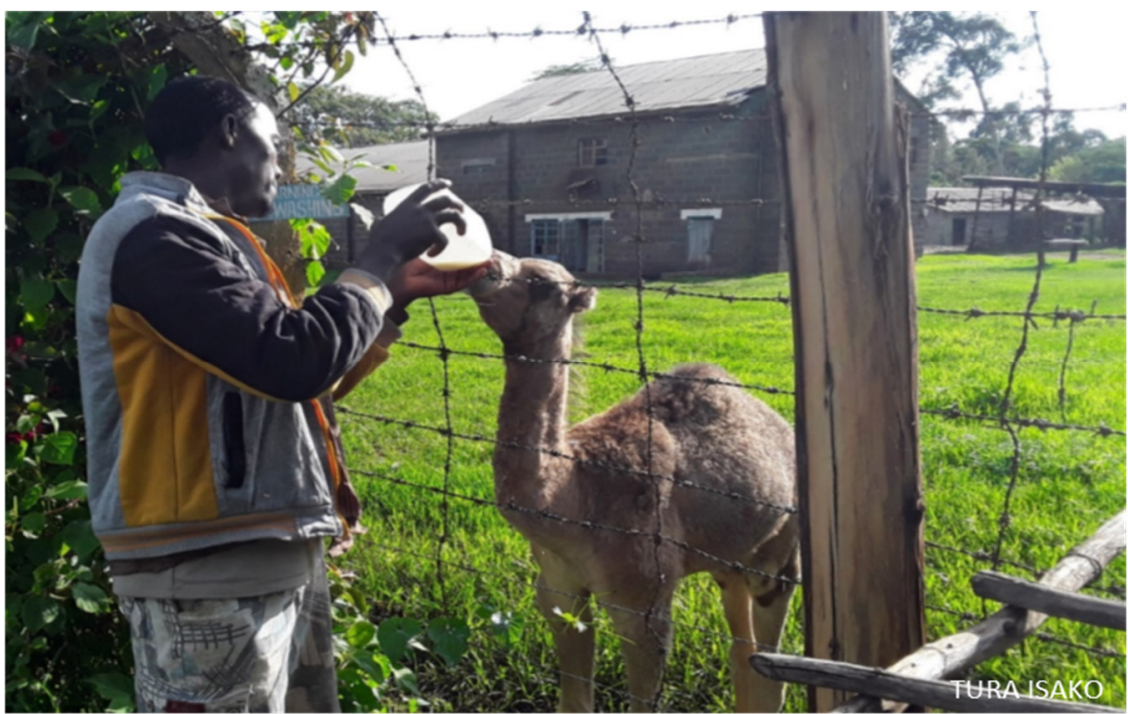

Photo 2: Fostering orphan calf with cow milk.

Below, table 1 shows the milk feeding regime of orphan calf until it attains full rumination.

Table 1. Guide to the amount of milk to feed to orphan camel calves

\begin{tabular}{|c|c|c|c|}
\hline Age of camel calf & $\begin{array}{l}\text { Approximate weight of camel } \\
\text { calf (kg) }\end{array}$ & $\begin{array}{l}\text { Number of feeds } \\
\text { per day }\end{array}$ & $\begin{array}{l}\text { Maximum amount } \\
\text { per feed (litre) }\end{array}$ \\
\hline Up to 1 week & $40 \mathrm{~kg}$ & $\begin{array}{l}\text { Up to } 8 \\
\text { (initially colostrum, } \\
\text { 2-hourly) }\end{array}$ & $3 / 4$ litre \\
\hline 2 to 4 weeks & $50 \mathrm{~kg}$ & 6 (4-hourly) & 2 litres \\
\hline Up to 2 months & $70 \mathrm{~kg}$ & 4 (6-hourly) & $3 \frac{1}{2}$ litres \\
\hline Up to 3 months & $90 \mathrm{~kg}$ & 3 (8-hourly) & $4 \frac{1}{2}$ litres \\
\hline Up to 4 months & $110 \mathrm{~kg}$ & 2 (12-hourly) & $3 \frac{1}{2}$ litres \\
\hline Up to 5 months & $130 \mathrm{~kg}$ & 1 (24-hourly) & $31 / 2$ litres \\
\hline
\end{tabular}

Source: Coventry, 2010

\subsection{Feeding calf on milk replacer}

Milk replacer is a consistent quality feed to meet the growth and development of the young calf. Possible benefits of accelerated calf growth include, increased long-term growth rate, improved responsiveness to hormones, improved milk production, immune system enhancement, and improved efficiency of gain (Wilson, 1984). Milk replacers are commonly used for cattle calves where the demand for milk for human consumption is high. Ingredients in milk replacers can vary widely and are most commonly milk or plant based. Plant based formulations (usually soy or wheat) are less expensive, but milk proteins are much more digestible for young calves. Milk based ingredients include dried whey, dried skimmed milk, milk protein concentrate, dried buttermilk, casein and delactosed whey. Table 2 shows recommendations for milk replacers and starter feeds for various livestock species.

Table 2. Recommended energy, protein, fibre, calcium, and phosphorus in milk replacer (MR) and starter feed (SF) in pre-ruminant cattle buffalo, sheep, goat, camel and yak

\begin{tabular}{|lllllllll|}
\hline Species & Feed & $\begin{array}{l}\text { ME (MJ/kg } \\
\text { of DM) }\end{array}$ & CP (\%) & EE (\%) & ADF (\%) & NDF (\%) & Ca (\%) & P (\%) \\
\hline Cattle* & MR & $15.8-20.1$ & $18-22$ & $10-20$ & - & - & 1.0 & 0.7 \\
\hline & SF & $13.0-14.6$ & $16-18$ & $3-5$ & $4-8$ & $12-18$ & $0.6-0.7$ & $0.4-0.5$ \\
\hline Buffalo & MR & $20.0-21.0$ & $18-22$ & $15-25$ & - & - & 1.2 & 0.9 \\
\hline & SF & $13.0-14.6$ & $16-18$ & $3-5$ & $4-8$ & $12-18$ & $0.8-0.9$ & $0.6-0.7$ \\
\hline Sheep & MR & $20.0-21-0$ & $20-24$ & $20-30$ & - & - & 1.2 & 0.9 \\
\hline & SF & $13.0-14.6$ & $18-20$ & 5 & $2-4$ & $8-12$ & $0.8-0.9$ & $0.6-0.7$ \\
\hline Goat & MR & $15.8-20.1$ & $18-22$ & $10-20$ & - & - & 1.0 & 0.7 \\
\hline & SF & $13.0-14.6$ & $16-18$ & $3-5$ & $2-4$ & $8-12$ & $0.6-0.7$ & $0.4-0.5$ \\
\hline Camel** & MR & $15.0-20.0$ & $20-24$ & 10 & - & - & 1.0 & 0.7 \\
\hline Yak & MR & - & $25-30$ & $25-30$ & - & - & 0.8 & 0.9 \\
\hline
\end{tabular}

ADF, acid detergent fibre; Ca, Calcium; CP, crude protein; EE, ether extract, ME, metabolisable energy; NDF, neutral detergent fibre; $\mathrm{P}$, Phosphorus.

Source: *NRC (2001), **Coventry (2010). 


\section{Camel calf health and diseases}

Camel health management has been documented as a major challenge in pastoral communities (KCA, 2012). Despite the camel being a hardy animal and resistant to most of the diseases commonly affecting livestock such as Foot and Mouth Disease, East Coast Fever, Rinderpest, Contagious Bovine Pleuro Pneumonia and Lumpy Skin Disease (KCA, 2012) camels were found to be susceptible to a large number of pathogenic agents (Al-Ruwaili et al., 2012). The calf is susceptible to diseases at early stages of life because of low immunity, its feeding, handling and housing is crucial at this time because of predisposing factors (Tibary and Anouassi, 2001).

Prevention of the calf diseases is important to cut the cost of production and increase survival rate of calves ensuring the progression of the camel generations. For almost all animal health problems, pastoralists have local herbs that they use for treatment; implying a wealth of indigenous knowledge on diseases and treatment (Wanyama, 1997). There are a lot of plants used as medicine in Samburu (Wanyama, 1997). Preparation of the medicines is cumbersome leading to variation of quantities administered which may result in over- or under-dose which can lead either to death or resistance. For instance, engine oil was applied with or without an acaricide to calves infested with ticks or mange, lead to negative effects because pheromones were masked resulting to calf rejection and heat problems (Fraiser and Broom, 1997). Ticks suck blood from the calves causing tick borne diseases, anaemia and paralysis (Schwartz and Dioli, 1992).

Megersa (2014) reported that the most prevalent camel calf diseases among camel herds of Borana community in southern rangelands of Ethiopia were sarcoptic mange (47.9\%), ticks (25.6\%), contagious skin necrosis $(15.8 \%)$, abscess (19.2\%), contagious ecthyma (9.4), camel pox (6.5\%), diarrhea (5.1\%) and respiratory infections $(4.5 \%)$. In the same study, mange and mite was reported to be prevalent during the dry than wet periods while contagious ecthyma, pox, respiratory infection and dermatophytosis were reported to be prevalent during the wet seasons. Many calves (over 70\%) tested positive for endo-parasites including Stronglyles, Strongyloides papillosus, Monezia and Eimeria species, indicating importance of parasitic burden. In the same study, the major causes of calf death were reported as septicemic diseases (35\%), respiratory infections $(22 \%)$, sunken eye or Elgof $(11 \%)$ and calf diarrhea (11\%). Mortality was significantly higher for wet season than dry period and had decreased with increasing age. Additionally, prevailing tradition of restricting colostrum intake among pastoralists and poor veterinary services might have a putative role on the increased early mortality of camel calves and should be improved.

\subsection{Scours in camel calves}

Many factors contribute to calf mortality, among which is calf diarrhea. Diarrhea is an economically important disease causing great losses in camel calves all over the world (Mohammed et al., 2003). Ali et al., 2005 reported a mortality of $39.9 \%$ in Sudan due to diarrhea in camel calves. Most of the fatal diarrhea cases among newly born camel calves are suspected to be caused by namely viruses, bacteria and protozoa. A study in Saudi Arabia (AlRuwaili et al., 2012) conducted in 184 diarrheic camel calves under 12 months old detected $14.7 \%$ group A rotavirus and $8.98 \%$ Brucella abortus. Escherichia coli was isolated from $58.2 \%$ of diarrheic calf camels while Salmonella spp. and Enterococcus spp. were detected in $12 \%$ and $8.8 \%$ of the specimens, respectively. It is recommended that the diseases can be controlled through vaccination of mature pregnant dams and calve diarrhea through oral re-hydration and administering Sulphur based drugs.

\subsection{Preventing scours in camel calves}

Diarrhoea (scours) can have life threatening effects, commonly in new born animals in different livestock species (Reichenbach and Amaral-Phillips, 2006) and upholding satisfactory standards of cleanliness and immunity are two key objectives when preventing it in camel calves. Early detection of scours can be achieved through measuring rectal temperature. Temperatures exceeding $40^{\circ} \mathrm{C}$ for more than one day, reduced milk intake, weakness, or watery and/or bloody stool can indicate the presence of a disease which causes scours. Records regarding camel calf disease prevalence should be maintained so that problems can be identified quickly and corrections implemented. Colostrum should be administered within the first six hours after birth, since IgG present in the colostrum, are used to fight the diarrhoea-inducing bacteria in calves. Sustaining good nutrition and vaccinations for in-calf dams will provide the new born with a healthy start.

KCA (2012) proposed a number of diarrhoea management approaches. The first approach addresses rehydration of the camel calf by using a mixture of water, table salt and honey ( 5 table-spoonsful of honey or sugar, 1 table-spoonful of table salt mixed with two litres of clean water). Administer $500 \mathrm{ml}$ of the solution orally every 4 hours until diarrhoea stops. The second approach proposed treatment of diarrhoea using eggs from chickens living in camel environment, orally administered one egg per day to a calf until diarrhoea stops. The third approach proposed use of conventional anti-diarrhoea drugs preferably Sulphur based drugs administered according to manufacturer's instructions. It has been observed sulphur based drugs are more effective for camel calf diarrhoea management. 


\section{Weaning with good quality forage}

The camel calf weaning age depends on environmental and genetic factors (Lasley, 1987) and on health status of the calf and production aims. When the objective is to increase herd, camel calves may be weaned early to allow early conception of the dam or may be delayed to prolong the lactation. The environmental aspects include the nutrition of the embryo in uterus and after birth through the milk production of the dam (Noor, 1999). A calf weaning age in normal circumstances is 6 to 12 months (Noor, 1999). Among Somali, a calf weaning age is 8 to 18 months (Farah et al., 2004) and it ranges from 8 to 12 months among the Samburu (Peter, 2010). Among Gabra and Rendille camel keeping communities in Northern Kenya, weaning age for camel calve is 12-18 months. The weaning age is important for determining economic efficiency of a production system (Wilson, 1998) while the weaning weight determines reproduction efficiency of the herd. Thus, an efficient system is expected to have high growth of calves implying calves will mature quickly and be weaned at an early age. At 12 months, camel calves can be weaned on high quality forage like lucerne hay. The concept of planted forages for camel feeding is not currently practiced in Kenya because camels are reared under extensive free-range systems. However, it is practical to manage and feed natural forages to promote faster growth. Some important range forage species that can easily be used for supplementation include shrubs like Salvadora persica, Tinnospora caffra, Acacia Tortilis Euphorbia tirucalli, and Balanites aegyptiaca and herbs like Barleria spp. and Blepharis linarifoloia.

\section{Conclusion and Recommendations}

Camel calves are the foundation of a camel herds and form the replacement stock without which herd growth is unlikely. Poor management practices are cited among the reasons why a large number of calves die in Kenya's pastoral camel herds. Good camel neonate management ideally start before birth. Pregnant dams should be grazed in flat open areas with good forages and frequently supplied with clean water. To avoid still births and weak calves, provide dams with adequate minerals and vitamins during pregnancy period. In addition, dams should not be subjected to long distance movement/trekking within the last two to three weeks before calving. Vaccination of pregnant dams and proper health management is key to calve survival and faster growth. In-calf dams should be closely observed during the day and night to avoid accidents and dams straying during parturition. Night enclosures should also put in flat grounds with less slippery soils preferably ground with sandy soil. The enclosures should also protect the dams and calves from predators like leopards, lions and hyenas.

It is important to note from the review that, newly born calf purely depend on colostrum suckling to acquire necessary antibodies to fight diseases like calf diarrhoea. It is imperative that within the first six hours of life colostrum suckling is maximized. If calf is unable to suckle on its own after birth, milk the dam and feed 8-10\% of its body weight within two to three hours of birth and repeat the same after every 4-5 hours. For instance, if calf is born with birth weight of $30 \mathrm{~kg}$, it requires about 2-3 litres of colostrum. The quality of colostrum is best in the first 24 hours of birth and calf should take maximum colostrum to acquire antibodies required to fight diseases. The colostrum is also critical for calf growth and survival in its life time.

Camel calf mortality is highest during the first 3 months of life and calf score is cited as a single major cause of calf mortality. Calf diarrhoea can be avoided by proper colostrum suckling/ feeding and regular milk suckling or feeding the calf. The calf can be suckled in the morning and evening. The calf should be allowed to get at least $50 \%$ of milk from the dam on daily basis (calf should be left to suckle two teats). Over feeding young calf can also result to bloat and secondary infections. If you are hand feeding, feed $8-10 \%$ of its body weight in milk on daily basis. Introduction of calf to browse and water as early as one to two months will stimulate early ruminal development. Mortality is also common during weaning in extensive pastoral production system. Supplement weaners with quality forages, clean water and minerals. Deworming during weaning is a recommended management practice.

From the foregoing it is recommended that future research on camel calves should target: 1 . Camel calve nutrition aiming to enhance calves' survival, growth and development via the science of epigenetics 2 . Calve diarrhoea and health 3. immunology 4. Uses of milk replacers and starter feeds in camel calves' nutrition as a solution to household milk competition. 5. Consolidating best bet management practices and indigenous knowledge from camel keeping communities. 6. Evaluation of camel calves under different production systems (peri-urban, extensive pastoral production system, ranching, and intensive system).

\section{References}

Al-Sultan S.I. (2008), "Effect of ascorbic acid in colostrum-deprived neonatal camels", Journal of Camel Practice and Research 15(2):191-193.

Ali Y., Khalafalla A.I., \& El Amin M.A. (2005), "Epidemiology of camel calf diarrhea in Sudan. Seroprevalence of camel Rotavirus infection", Journal of Animal and Veterinary Advances 4(3):393-397.

Al-Ruwaili M.A., Khalil O.M. \& Selim S.A. (2012), "Viral and Bacterial Infections associated with Camel (Camelus dromedarius) Calf Diarrhoea in North Province, Saudi Arabia", Saudi Journal of Biological Sciences 19, 35-41. 
Bekele M. (2014), "Major diseases of camel calves in Borana of Southern Ethiopia. African journal of basic \& applied sciences 6(6):159-165.ISSN 2079-2034.

Bakheit S.A., Faye B., Ibrahim I.E. \& Idris A.O. (2017), "Effect of Management System on Camel Calves Growth rate and Daily gain", Direct Research Journal of Veterinary Medicine and Animal Science, 2(1):8-13.

Browne A.S. \& Deem S. (2012), "Herd Health Protocols for Dromedary Camels (Camelus dromedarius) at Mpala Ranch and Research Centre, Laikipia County, Kenya".

Coventry, J. (2002), “Orphan Camel Calves: First Feed”. In Agnote, No. J82.

Donahue, M., Godden S.M., Bey R., Wells S., Oakes J.M., Sreevatsan S., Stabel J., Farah Z., Mollet M., Younan M. \& Dahir R. (2007), "Camel Dairy in Somalia: Limiting factors and development potential", Livestock Science, 110, 187-191.

Farah, K.O., Nyariki, D.M., Ngugi, R.K., Noor, I.M. \& Guliye, A.Y. (2004), “The Somali and the Camel: Ecology, Management and Economics"' Anthropologist, 6(1): 45-55.

Field, C.R. (1979), "Camel growth and milk production in the Marsabit District". In: Cockrill, W.R. (Ed.). The camelid, An all-purpose animal, Scandinavian Institute of African Studies, Uppsala, Sweden. pp.209-230.

Fraiser A.F. \& Broom D.M. (1997), "Farm Animal Behaviour and Welfare”, Camel International. 219 -226.

Godden, S. M., Smith S., Feirtag J.M., Green L.R., Wells S.J., \& Fetrow J.P. (2003), "Effect of on-farm commercial batch pasteurization of colostrum on colostrum and serum immunoglobulin concentrations in dairy calves", J. Dairy Sci. 86:1503-1512.

Godden, S. M., Smolenski D.J., Donahue M., Oakes J.M, Bey R., Wells S., Sreevatsan S., Stabel J., \& Fetrow J. (2012), "Heat-treated colostrum and reduced morbidity in pre-weaned dairy calves: Results of a randomized trial and examination of mechanisms of effectiveness", J Dairy Sci., 95(7):4029-4040

Johnson, J. L., Godden, S.M., Molitor T., Ames T., \& Hagman D. (2007), "Effects of feeding heat-treated colostrum on passive transfer of immune and nutritional parameters in neonatal dairy calves", J. Dairy Sci. 90:5189-5198.

Kamber R., Farah Z., Rusch P. \& Hassig M. (2001), "Studies on the supply of immunoglobin G to newborn camel calves (Camelus dromedaries)", J. Dairy Res. 68(1):1-7.

Kaufmann, B.A. (2003), "Difference in Perception of causes of camel's calf losses between pastoralist and scientists". Cambridge Journals abstract.

Kertz A.F., Hill T.M., Quigley III J.D., Heinrichs A.J., Linn J.G., \& Drackley J.K. (2017), “A 100-Year Review: Calf nutrition and management", J. Dairy Sci. 100:10151-10172.

Kuria S.G., (2004), "Mineral Nutrition on settlement (manyattas) based milk camel herds among Rendille community of northern Kenya", PhD thesis. University of Nairobi.

Lasley J.F., (1987), “Genetics of Livestock Improvement. Department of Animal Husbandry”, University of Missouri. pp 13.

Malmuthuge, N., Chen Y., Liang G., Goonewardene L.A., \& Guan L.L. (2015), "Heat-treated colostrum feeding promotes beneficial bacteria colonization in the small intestine of neonatal calves", J. Dairy Sci. 98:80448053

Mohammed M.E., Hart C.A., \& Kadden O.R. (2003), "Viruses and bacteria associated with neonate camel calf diarrhea in eastern Sudan", Emir. J. Agric. Sci., 15(1):56-62.

Noor, I.M. (1999), “A description of the pastoral camel production system in Moyale District, Kenya”. MSc. Thesis, University of Nairobi.

Peter M.I. (2010), "An Analysis of camel calf growth and survival under pastoral production system in Samburu”, MSc. Thesis, $124 \mathrm{pp}$, University of Nairobi.

Ontsouka, E.C., Albrecht C., \& Bruckmaier R.M. (2016), "Growth-promoting effects of colostrum in calves based on interaction with intestinal cell surface receptors and receptor-like transporters: Invited review," J. Dairy Sci. 99:4111-4123.

Reichenbach H.B. \& Amaral-Phillips D. (2006), "How to prevent scours in dairy calves. Extension service reports".' College of Agriculture, food and environment, University of Kentucky.

Schwartz H.J. \& Dioli M. (1992), "The one-humped camel in Eastern Africa A pictorial guide to diseases, health care and management", Verlag Josef Margaf Scientific books, Wekersheim, Germany.

Stewart, S., Godden, S., Bey R., Rapnicki P., Fetrow J., Farnsworth R., Scanlon M., Arnold Y., Clow L., Mueller K., \& Ferrouillet C. (2005), "Preventing bacterial contamination and proliferation during the harvest, storage, and feeding of fresh bovine colostrum", J. Dairy Sci. 88:2571-2578.

Tibary A. \& Anouassi A. (2001), "Neonatal Care in Camelids. Recent Advances in Camelid Reproduction", L. Skidmore and G. P. Adams (Eds.) Publisher: International Veterinary Information Service (www.ivis.org), Ithaca, New York, USA.

Tura I., Omondi S.P., Esther M.N., Keya G.A.2010. Vision and upgrading strategy of camel meat and milk value chain in Kenya. Conference paper in the symposium of animal production society of Kenya ,2010.

Wanyama J.B. (1997), "Confidently Used Ethno veterinary Knowledge among Pastoralists of Samburu", 
Intermediate Technology Kenya.

Wilson, R.T. (1984), “The camel”, Longman Group Ltd. Harlow, Essex, UK. Pg. 1-223.

Wilson, R. T. (1998), “Camels”, The Tropical Agriculturalist, CTA, the Netherlands.

\section{About the Authors}

1. Tura Isako- Principal research scientist with Kenya Agricultural and Livestock Research Organization (KALRO). PhD student at Egerton University, Njoro, Kenya.

2. King'ori A. M - Senior Lecturer at Egerton University, Njoro, Kenya.

3. Ondiek J. O - Senior Lecturer at Egerton University, Njoro, Kenya.

4. Onjoro P. A- Senior Lecturer at Egerton University, Njoro, Kenya.

\section{Acknowledgement}

The authors sincerely acknowledge Egerton University and Director General, Kenya Agricultural and livestock Research organization (KALRO) 